\title{
USE OF MEANS OF UKRAINIAN FOLK PEDAGOGY IN FORMATION OF MORAL AND ETHICAL CONCEPTS IN EXTRACURRICULAR EDUCATIONAL WORK
}

\author{
MARIIA KOPCHUK-KASHETSKA
}

\begin{abstract}
The article identifies the peculiarities of the formation of moral and ethical concepts of students in extracurricular activities. In particular, positive influence of means of Ukrainian folk pedagogy on the education of moral qualities of students is revealed. Folk-pedagogical methods of stimulation, encouragement, motivation of children, and correction of their behavior are outlined. The process of formation and development of desirable moral qualities in children takes place in a close relationship between learning and education, as it is impossible, in the educational process to aim at the formation of some moral and ethical values, and in extracurricular educational work others. The effectiveness of the process of moral and ethical education of children largely depends on the purpose and those educational tasks set by the teacher (educator), pedagogical tools and forms of organization of the pedagogical process, the principles of systematic and pedagogical cooperation of school and family in solving this problem. It proved to be a great loss to neglect the achievements of folk pedagogy, especially when it comes to raising the level of morality of schoolchildren. Two directions: cognitive and applied are carried out in the process of formation of moral and ethical concepts of education of students in extracurricular educational work, as well as in educational activities. This means that students, in addition to mastering and deepening theoretical knowledge, have opportunities for their practical application.
\end{abstract}

Keywords: Ukrainian folk pedagogy, moral and ethical concepts, extracurricular educational work, folk means of socialization, folk pedagogical methods, social behavior.

\section{INTRODUCTION}

The more opportunities for mastering knowledge of moral and ethical values, understanding the essence of certain moral categories, discussion of folklore and relevant topics, etc., i.e., favorable conditions for the fullest use of intellectual potential of students are in the educational process, the more attention is paid to the formation of students' need for moral and ethical acts in extracurricular educational work of teachers and educators. But this does not exclude the importance of motivational and behavioral components of moral and ethical education of the student's personality in extracurricular educational work, because, as already noted, all components of this phenomenon are closely interrelated.

Forms of organization of extracurricular activities aimed at educating moral and ethical values in children, according to the time factor are traditionally divided into systematic and episodic.

- Systematic forms of organization, as a rule, function for a long time and have a permanent membership (circles, sections, interest clubs, etc.). 
- Episodic ones are held periodically (competitions, contests, tours, exhibitions, etc.).

According to the method of organization, there are mass, group and individual forms of extracurricular educational activities.

\section{ANALYSIS AND DISCUSSION}

Analysis of scientific literature and conducted experiments in this branch of theory of education suggests that the set of forms and methods of development of moral and ethical values of junior high school students includes: explanatory conversation (expanding the range of spiritual, moral, ethical understanding, moral - ethical situations, choices of action (real or verbal), ethical actions of the individual (actions of the teacher), real implementation of ethical actions by students, evaluation of actions, etc.

Depending on life experience of students, their individual particularities, the system of moral and ethical values and ethical knowledge that has formed, the area of sectors of this circle may be different.

For example, if a student doesn't show special abilities to learn, has poor ethical concepts, the teacher pays more attention to communication, gives the examples of various ethical actions of people, which reflect their moral and ethical values [6].

As extracurricular educational work, in contrast to lessons, is less regulated in time, you can insist on the diversity of Ukrainian ethnography (language, traditions, customs, rites, rituals, etiquette, beliefs, shrines, folklore, games, toys, clothing, holidays, ceremonies, crafts, symbols of others) and their usage in the process of moral and ethical education of young students.

It is a well-known fact, V. Strumansky proposes to classify the means of Ukrainian folk pedagogy, because of all the multifaceted influence of folk pedagogical tools on the formation of the child's personality [6]. We can distinguish the priority of each of them in cultivating certain qualities. Thus, spiritual and moral values are formed primarily through the study of folk rites, holidays, theatrical games and festivities according to folk scenarios and with the use of established symbols and attributes. The intellectual sphere of the student is enriched through observation of natural phenomena, mastering folk mathematics, solving riddles, developing cleverness, analytical thinking and memory. The information is presented below in the table 1 .

\begin{tabular}{|c|c|}
\hline Group of education means & Indication of selection \\
\hline $\begin{array}{l}\text { 1) culturological (customs, traditions, holidays, symbols, attributes ...); } \\
\text { 2) spiritual (language, folklore, folk morality, rules of etiquette ...); } \\
\text { 3) practical (work, games, folk calendar of seasonal field work ...); } \\
\text { 4) correctional (punishment, intimidation, physical action ...) }\end{array}$ & By content \\
\hline $\begin{array}{l}\text { 1) folklore-epic (native language, elements of folklore, epic...) and } \\
\text { figuratively symbolic (folk song, legends, fables, lies, proverbs, riddles } \\
\text {...); } \\
\text { 2) means of activation and development of production and economic } \\
\text { potential of the individual (Various forms of labor participation of the } \\
\text { child in everyday life of families, families, communities, folk crafts and } \\
\text { crafts ...); } \\
\text { 3) folk customs and traditions (traditions of respectful attitude to the } \\
\text { land-sustainer, customary actions of the spring cycle - gaivki, gagiilki, } \\
\text { vesnyanki ...); } \\
\text { 4) corrective means (punishment, intimidation, physical action ...) }\end{array}$ & $\begin{array}{l}\text { According to the source of } \\
\text { the dominant influence on } \\
\text { the consciousness, feelings } \\
\text { and will of the child }\end{array}$ \\
\hline
\end{tabular}

Tab. 1. The structure of the main folk remedies for socialization of the child. 
Extracurricular activities directly or indirectly serve to activate the moral and ethical habits and behavioral skills of ethnography (for example, regarding the conduct of ethnographic observations; fixation of folklore; memorization and performance of Ukrainian folk songs; involvement in Easter painting, etc. In this context it is allowed to use such methodical receptions which not always and to the full extent can be used at a lesson.

In folk pedagogy there is a group of corrective means, including various forms of corporal punishment. In the Ukrainian Christian family there was a great respect for the parents and the unquestioning obedience of the younger ones was preached to the elders. At the same time, people foster a humane attitude and demanding love for the child, that is, declare the mandatory compliance of the pedagogical requirements for the child with universal respect for one's personality.

In this view, educational work with young students stressed the principle of humanization of interpersonal relationships between all the participants of the pedagogical process, which provides for equal ties that exclude rude subordination of the child to the will of an adult.

Humanistically oriented personality, as noted by I. Bech, indicates the meaning of existence in the constant creation of universal moral acts as a practical embodiment of the relevant moral qualities [1].

At the same time, "only a humane educator can educate a humane person", so this position was widely promoted in the process of research and experimental work" [1].

The formation and development of moral values of junior high school students in extracurricular activities can be divided into four groups:

1) morals and attitudes towards parents and senior family members, neighbors, teachers, friends;

2) morality and attitude to educational and domestic work;

3) morality and attitude to the natural environment, objects of material and spiritual culture;

4) morality and attitude to oneself.

Considering more detailed results of observation of moral and ethical behavior of students, attitude to the natural environment, attitude to people around, attitude to learning and work and attitude to themselves.

In the attitude of students to loved ones, relatives are noticeable manifestations of volunteers, mercy, respect, respect, while the neighbors, strangers, children mostly do not show such feelings.

The solution to this problem can be found in Matthew 7:12, where the Lord gives the "golden rule of morality".

An important aspect of the formation of moral and ethical values is the assimilation by students of ethical norms of responsibility in interaction with other people, in the performance of their various duties. Moral responsibility presupposes any conditions, supporting one another, orienting oneself and accepting responses to the needs it reflects. Therefore, it is important for teachers to promote the development of empathy in students, because not only the inner state of another person is reported, but also employees, cooperation, effective participation in solving the problems of others. A study of the problem of empathy in primary school students shows that its level decreases every year.

This important moral value, which has long been inherent in the emotional and sensual nature of Ukrainians, is leveled mainly by underestimating its significance. Folk educational practice has always resorted to the inner world of man, appealing to his honor, conscience, shame ("Conscience is the best adviser", "Although shame does not leave the eyes, but does not allow people to appear", "Conscience gnaws without teeth", etc.), which emphasizes the awareness of folk educators of the effectiveness of three interrelated components of human character - moral knowledge, moral feelings and moral behavior [5].

In terms of self-attitude one should listen to the emotional component that determines the level of development of moral and ethical consciousness of young students (moral ideas, concepts, views, feelings), applying self-regulation between participants through messages that are responsible to society and personal moral value.

Personal feelings that show attitudes (conscience, pride, shame, modesty, etc.) are social. Speaking about the attitude of students to the natural environment and educational activities, the behavioral component (act) of moral and ethical education is significantly actualized. This expresses the degree of 
formation and stability of ethical content, navigator and habits, and motivational component, which is a system of dominant moral and ethical needs, motives of activity and behavior of the person.

According to I. Bekh, the peculiarity of the attitude of young students to moral requirements and norms (and in accordance with the assessment of their implementation) due to the peculiarities of the internal composition of the child: what motives really act, how the formation of a personality is created, because it contains people who had experiences in experience [2].

A famous american scientist E. Durkheim rightly operates with the concept of "rational autonomy of the individual", the essence of which defines "readiness to meet state requirements not only through external coercion and institutions, but as a result of rational communication of these needs" [8].

Primary school students have the power of a mismatch between knowledge of moral and ethical norms and rules and their behaviour, because they will not contain the relationship of existing ideas about the world around them to specific teachers. So, for example, often after educational activities ("On honesty and obedience", "On friendship and goods", "What is manifested by incomprehensibility?") Young people can take acts of deviant behaviour in the created before detection. In this regard, the study of the educator, highlighted by the student who educates peers, they react differently: one student looks at a shame for his teacher, deeply communicates a message that hurts someone; the other is not to suppress the feeling of shame, but only fear because of possible punishment; yet another believes that his conviction is indeed unjust.

The results of experimental work indicate that the organization of purposeful and systematic moral and cognitive activities allows young students to master the system of knowledge about the essence and significance of moral and ethical values, assimilated and realized by the essential features of moral concepts [10].

Forms of joint activities and communication of young students and have great opportunities for educational impact. An important fact is that most primary school teachers spend time with students in the classroom. Therefore, the education of moral and ethical content, navigation and habit, as well as moral and ethical values of young students is well placed on the basis of interaction and heritage between their classroom and extracurricular activities.

Extracurricular reading is an effective means of cognitive activity of students in ethnography, a source of their self-education in the field of mastering moral and ethical norms. In recent years, many valuable books on this topic have appeared, as well as very interesting, informative and fully accessible, at least for younger students. V. Skurativsky's books "Berehynia", "Pokut", "Pohostyny" are very popular among primary school students. Useful in preparing for extracurricular reading classes for teachers were, for example, a two-volume work by O. Voropay "Customs of our people", S. 7.Plachynda, textbook "Culture and life of the population of Ukraine", books by Y. Kruglyak "The name of your city", O. Pasternak "Explanation of the trident", O. Zhygalenko "Where are you going, the Milky Way", V. Davydyuk "Ukrainian mythological legend" and others. The newspaper "Ethnography" by M. Dmytrenko and "Living Water" by D. Cherednychenko, which systematically publish very interesting materials on Ukrainian studies, which were successfully used by us in extracurricular work, became a significant benefit for teachers and students in the process of research.

Thus, important folk-pedagogical methods of stimulating, encouraging, motivating students, correcting their behavior can be considered as follows:

- creating a collective opinion of approval, analysis of the act (behavior) or condemnation of the child's actions;

- various forms of encouragement, motivation to commit ethical acts;

- arousal of interest in the ultimate interest of the activity, the disclosure of the expected joy from it;

- formation of a conscious need to prohibit the negative, distorted and warn the child against reckless acts;

- suggestion to use to behave and live so as to support the praise of parents, teachers, dear surroundings, peers;

- use of various folk methods of identifying the child for active behavior; 
- study and discussion of Ukrainian folklore about moral and ethical ideas, traditions and customs of our people;

- involvement in the mastery of folk crafts and handicrafts.

\section{CONCLUSIONS}

Thus, within the framework of the study of this topic, we have defined traditional folk-pedagogical methods of forming the child's social behaviour which proved effective in accumulating students' life experience:

- training in conscientious performance of duties at school, family, surrounded friends, both users to society;

- speed of constant and one-time assignments and exercises for the manufacture of certain abilities and skills;

- practical life of students in the performance of various roles of worker, worker, family man;

- ensuring generally accepted norms and traditions of the way of life of Ukrainians [5].

Definitely, extracurricular educational work alongside with lessons provid significant background for the formation of moral and ethical concepts within the ethnographic direction of education.

\section{REFERENCES}

[1] Bekh I.D. Psychological essence of humanism in the education of personality. Pedagogy and psychology, 3 (1994), 3-12. (in Ukrainian)

[2] Bekh I.D. Personally oriented approach: theoretical and technological principles, book 1. In: Bekh I.D. Education of personality, in 2 books. Lybid, Kyiv, 2003. (in Ukrainian)

[3] Voznyuk N.M Ethical and pedagogical foundations of personality formation, a textbook. Center for Educational Literature, Kyiv, 2005. (in Ukrainian)

[4] Budnyk O. Ethnopedagogy of economic education of schoolchildren, scientific and methodical manual. IvanoFrankivsk, 2005. Available at: http://194.44.152.155/elib/local/878.pdf. (in Ukrainian)

[5] Skulsky R.P. (Ed.) National education of students by means of Ukrainian ethnography. Ivano-Frankivsk, 1995. (in Ukrainian)

[6] Strumansky V.P. Educational work in the national school, a textbook. IZMN, Kyiv, 1997. (in Ukrainian)

[7] Kopchuk-Kashetska M.S. Formation of moral and ethical values of junior schoolchildren by means of Ukrainian ethnography, monograph. YARYNA, Ivano-Frankivsk, 2017. (in Ukrainian)

[8] Krasovitsky M. Moral education of students in the theory and practice of the American school: Experience and problems. Handbook for teachers. Native school, 4 (1998), 29-52. (in Ukrainian)

[9] Tsyunyak O. Peculiarities of family upbringing in the conditions of a mountainous village. Mountain School of Ukrainian Carpaty, 11 (2014), 233 - 235. (in Ukrainian)

[10] Vasianovych H., Budnyk O., Klepar M., Beshok T., Blyznyuk T., Latyshevska K. Pragmatism in Philosophy of Inclusive Education Studies and Problems of Teacher Training. Revista Inclusiones, 7 (4) (2020), 59-73.

Address: Mariia Kopchuk-Kashetska, Vasyl Stefanyk Precarpathian National University, 57 Shevchenko St., Ivano-Frankivsk 76018, Ukraine.

E-mail: mariia.kopchuk-kashetska@pnu.edu.ua.

Received: 01.03.2021; revised: 27.03.2021. 
Копчук-Кашецька Марія. Використання засобів української народної педагогіки у формуванні морально-етичних понять у позаурочній виховній роботі. Журнал Прикарпатського університету імені Василя Стефаника, 8 (1) (2021), 212-217.

У статті визначено особливості формування морально-етичних понять школярів у позаурочній діяльності закладу загальної середньої освіти. Зокрема, виявлено позитивний впдив засобів української народної педагогіки на виховання моральних якостей учнів, окреслено народнопедагогічні методи стимулювання, серед яких: заохочення, спонукання та корекції їх поведінки дітей. Процес формування та розвитку моральних якостей у дітей відбувається у тісному взаємозв'язку навчання, розвитку та виховання, тобто не можна, наприклад, в освітньому процесі ставити за мету формування одних морально-етичних цінностей, а у позаурочній виховній роботі - інших. Результативність процесу морально-етичного виховання дітей значною мірою залежить від мети і тих виховних завдань, які ставить перед собою вчитель (вихователь), педагогічних засобів і форм організації освітнього процесу, принципів систематичності та педагогічної співпраці школи та сім'ї у вирішенні окресленої проблеми. У процесі формування морально-етичних понять в учнів у позаурочній виховній роботі, як і в навчально-пізнавальній діяльності, здійснюеться у двох напрямах: пізнавальному та прикладному. Це означає, що учні, поруч із опануванням та поглибленням теоретичних знань, мають можливості для їх практичного застосування.

Кдючові слова: студентське самоврядування, освітній процес, якість освіти, вища освіта, лідерство. 